\title{
中国・少数民族伝統体育運動会にみるアイデンティティの諸相
}

\author{
渡邊 昌史
}

\section{Aspects of identity seen at national meets involving traditional athletic sports among ethnic minorities in China}

\author{
Masashi Watanabe
}

\begin{abstract}
The People's Republic of China, which is a multiethnic country, considers policies focusing on ethnic minorities to be an imprtant national issue. The present study was designed to examine the identity of ethnic minorities by focusing on national meets involving traditional athletic sports among such ethnic minorities as one aspect of national policy. The 1st and 7th National Meets of Athletic Sports for Ethnic Minorities were held respectively in 1953 and in 2003, during which a change from modern sports to ethnic sports was recognized with respect to the sporting events emphasized. Subsequently, a change from those ethnic sports to post-ethnic sports was recognized. The participation of members of minority groups in these National Meets appeals to their ethnic identity, leading to the creation of a pan-ethnic minority identity. Since in addition to ethnic minorities, the Han race also participates in the National Meets, the Meets function as a cultural mechanism by which the Pan-ethnic minority identity is replaced by the Chinese ethnic identity, thus equating the Chinese ethnic identity with the official national identity. The representation of culture at the National Meets has been changing from a state in which "ethnic minorities represent different cultures" to one in which "ethnic minorities represent their own cultures." These facts suggest that ethnic sports in China contribute to political and ethnic integration, whereby ethnic sports are useful for affirming ethnic identities that are manifested at various intensity levels, and that ethnic sports serve as a medium whereby changes in identity can take place.
\end{abstract}

\section{Key words : ethnic sport, cultural change, post-ethnic sport}

(Japan J. Phys. Educ. Hlth. Sport Sci. 51: 287-298, May, 2006)

キーワード：民族スポーツ, 文化変化, ポスト

民族スポーツ

\section{I 問題の所在}

多民族国家の中華人民共和国（以下，「中国」

天理大学体育学部 (非常勤)

厂 632-0071 奈良県天理市田井之庄町 80

連絡先 渡邊昌史
Tenri University, Faculty of Health, Budo \& Sports Studies

80 Tainosho-cho, Tenri, Nara 632-0071 
という）は現在，総人口の約 92 パーセントを占 める漢族と, 残りの約 8 パーセント（約 9,056 万 人）の少数民族から成っている ${ }^{\text {ia } 1)}$. 中国は「民 族平等，民族団結」を憲法で明文化し国是の一つ としており，少数民族政策を重要な国家課題と位 置付けてきた。

本研究は中国の少数民族政策をめぐる少数民族 のアイデンティティの問題を，具体的には「全国 少数民族伝統体育運動会」(以下，「少数民族運動 会」とする）という場に着目して，その歴史と変 化から論じようとするものである.

少数民族運動会は主として少数民族が民族スポ ーツを競い，また「民族文化」をモチーフにした 歌舞を披露し合う全国的スポーツ・イベントであ り，1953年を㜴矢として 2003 年の大会が第 7 回 目に数えられている.

少数民族運動会にかかわる先行研究としてまず あげなければならないのは，邱（1995），李 （1999）によるものであり，いずれの論文も国家 政策としての少数民族政策及び少数民族運動会に みる変化を「発展」として捉えている。そうした 進化論的枠組みに基づく研究では，少数民族の文 化は漢族の文化に対し時間的差異をもつ存在とし て位置付けられてきた。

これに対し本研究は文化を時間軸ではなく空間 軸でとらえることにより，少数民族運動会によっ て醹成される少数民族のアイデンティティの問題 について明らかにしょうとする視座に立ってい る。また，併せて国民国家の「人民注 2 」形成と いう政治的動態のなかで，文化を表象することと 民族スポーツがどのような関係を取り結ぶのかに ついても論じようとするものである.

なお，本研究で用いた資料は論文末尾に挙げた 諸文献及びウェブサイトと，筆者が 1999 年 8 月 と 9 月に抢こなった第 6 回少数民族運動会の現地 調査で得られた情報から成っている。

\section{II中国における「少数民族」と 少数民族スポーツ政策}

\section{1. 少数民族の概念と民族政策}

複雑な民族構成をもつ中国史上において，1920
年代以前は漢族以外の民族集団を一まとめにした 少数民族というカテゴリーは存在しなかった（岡 本，1999，p. 34).

1949 年，中国共産党によって建国された中華 人民共和国の民族問題にかかわる基本目標は国家 の領域的統合，辺境の対外安全保障，忠誠心をも つ，均質な「人民」の形成であり，政策原則は民 族間の政治的・経済的平等であった（毛里，1998， pp. 45-47). 建国によって中央政府の統治下に編 入した漢族以外の諸民族（以下，「エスニック・ グループ」という）を「人民」として統合して行 くためには，その構成員をはっきりと確定し，境 界をつけた国家的・政治的領域にアイデンティテ イと帰属意識を抱かせる必要があった。それには 民族の識別と認知（いわゆる「民族識別工作」） が重要な役割を果たした。

建国当時，民族として認知されていたのは「五 族注 3 )」(漢族, 満洲族, モンゴル族, 回族, チベ ット族）の他にウイグル族，ミヤオ族，ヤオ族， イ族，朝鮮族を加えた 10 族に過ぎなかった。と ころが，中央政府が 1953 年に初めて実施した人 口センサスでは，自己申告に基づいて登録された 「民族名」が 400 以上にものぼった。そこで中央 政府は民族識別工作により分別，統合をおこなっ た結果注 ${ }^{4} ， 1979$ 年までに 55 の少数民族が認定さ れた注5)。これにより，エスニック・グループは 中国における「少数民族」という新たなステータ スを付与されたこととなった。

文化大革命期，中央政府は民族問題の存在を認 めず，民族工作自体が取り消された。

1980 年代に至って，リベラルな民族政策が推 し進められるようになり，そこでは，少数民族自 身からの要求も受け入れ，1981 年から 1985 年ま で民族籍の回復や変更を積極的に推し進めた。だ が，予想外にもおびただしい数の人々が少数民族 籍の回復や変更を求め, 少数民族が急増する結果 をもたらし，その数は 1986 年までに 260 万人に 達した注6).

ここで注目すべきは，はじめから「55の少数 民族」であったのではなく，エスニック・グルー プを中央政府が識別するという政治的行為によ 
り，今日においては中央政府公認の少数民族が 55 種類あるとされていることであり，これは中 国における「民族」，「少数民族」とは政治的かつ 状況的に形成された概念であることを教える。

\section{2. 少数民族スポーツ政策と全国少数民族運動 会}

民族スポーツが中央政府の少数民族政策のなか に組み入れられた契機は 1949 年 10 月，全国体育 工作会議にて「『広範囲に民間スポーツ形式を発 展させる』という民族スポーツ推進策を採決した」 （李，1998，p. 51）ことである。「伝統に対する このような視点は，国家のアイデンティティを伝 統文化に求める点で，ひとつの国家として文化的 に統合しょうという試みと考えることができ

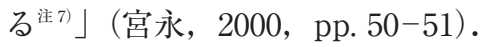

先述のように中央政府のねらいは，エスニッ ク・グループにも「人民」という帰属意識をもた せる「上からの国民形成」(毛里，1998，p. 74) にあった。それには前段階として「少数民族」と いう国家的ステータスを与え，彼らに自己認識さ せることが何よりも必要であった。そのために中 央政府は「少数民族の文化」を認定し，自己認識 化させるためにとられたのが少数民族に対する民 族スポーツ政策（以下，少数民族スポーツ政策と いう）であった。

換言すれば，中央政府の少数民族スポーツ政策 によって，エスニック・グループは民族スポーツ という文化を媒介として「少数民族」に，そして 「人民」となることが政治的に要請されたといえ よう。

少数民族の民族スポーツは国家的スポーツ・イ ベントとしては，まず初めに国際スポーツの競技 会の場において，その存在が公にされた。

1953 年 11 月，「全国民族形式体育表演及竞赛大 会」が天津市にて開催され，華北区，東北区，西 北区, 中南区, 西南区 (含西蔵), 内蒙古自治区, 人民解放軍，鉄道系統の 9 単位から，12の少数民 族（当時）及び漢族の選手 395 名が参加し, ウエ イト・リフティング，ボクシング，レスリング, フェンシング，ライフル射撃の国際スポーツ 5 競
技の他に，武術，民間体育，馬術など 383 種類の 民族スポーツが紹介された（中国体育博物館・国 家体委文史工作委員会，1990，pp. 782-783）。

1959 年 9 月には，1910年から 1948 年まで「全 国運動会」として7回開催されていた全国的総合 運動会が「中華人民共和国全国運動会」へと発展 的解消をみた。そこでは国際スポーツが主ではあ つたが，武術，中国将棋など幾つかの民族スポー ツも実施された。

だが，1956年 11 月から起こった文化大革命に より民族工作自体が消滅したこの一時期，少数民 族の民族スポーツのみならず，中国スポーツ界も また 1970 年頃まで休止状態に陥った。

「少数民族のスポーツの広範囲な実践と急速な 発展，そして国内諸民族からの要求を考慮した結 果」(邱，1995， p. 207），1981 年 9 月，国家民族 事務委員会と国家体育運動委員会（現在の国家体 育総局）は少数民族の民族スポーツに関する合同 会議を開催した。そして, 少数民族の民族スポー ツを「積極的に提唱し，指導を強化し，改革し， 着実な足取りで発展させる」方針を打ち出し, 少 数民族の民族スポーツの祭典を将来において再び 開催することを決議した（邱，1995，p. 207）。 これを受けて，民族スポーツの地方別大会や競技 会が開催されるなど，民族スポーツの全国組織化 がなされていった.

1982 年 9 月には内蒙古自治区フフホト市で 55 の少数民族と漢族から成る 29 代表団が参加し, 「全国少数民族伝統体育運動会」が開催された。 「少数民族運動会」の名称で開催された初めての 大会である。この大会より参加方式は各省，自治 区，直轄市単位となり，それぞれ複数の少数民族 によって構成された。比賽と表演の区分注8 を設 け，比賽は中国式摔跤と射箭，表演では 68 の民 族スポーツが実施された（中国体育博物館・国家 体委文史工作委員会，1990，pp. 783-785)。選手 団総勢 863 名のうち少数民族の選手は 593 名を占 めるが，残り 270 名のうちに少数民族の役員を認 めたとしても，少なからず漢族が参加しているの は特筆に值する。「この祭典を訪れた報道関係者 たちは，50を超える少数民族が兄弟のように集 
うことができるのは世界中だけでも中国だけ」 （邱，1995，p. 208）と称えたという.

1984 年，国家民族事務委員会と国家体育運動 委員会は，1953年の大会を漢族と少数民族が平 等に関わった歴史的なイベントであり，少数民族 の民族スポーツの歴史に新たな段階を切り開いた ものと再評価し,さかのぼって「第 1 回全国少数 民族伝統体育運動会」と認定するとともに，今後 は 4 年ごとの定期開催を決定した ${ }^{\text {注 9) }}$ (李，1999， p. 51).

定期開催となった第 3 回大会は 1986 年 8 月に新 疆ウイグル自治区ウルムチ市で，55の少数民族 と漢族による 29 代表団の総勢 1,097名（うち，少 数民族からは選手 777 名）が参加して, 射箭, 摔 跤，馬術，二羊，射驽，搶花炮，秋千の 7 競技及 び115の表演が実施された（中国体育博物館・国 家体委文史工作委員会，1990，pp. 785-787）.

1991 年 11 月には第 4 回大会が広西チワン族自 治区南寧市で開催され, 比賽は龍舟競渡, 搶花炮, 秋千，射驽，珍珠球，木球，摔跤，武術の 8 競技 及び 120 の表演が実施された ${ }^{\text {主 }}$. 初めて台湾の 高山族注 ${ }^{11}$ からも龍舟競渡チームと歌舞団を迎え, 「台湾海峡の両側の少数民族の団結が実現」（邱, 1995，p. 210），30 代表団と視察団，内外の記者 を含め関係者は 3,000 名を超えた（第 6 回全国少 数民族伝統体育運動会拉薩分賽場専刊編集部, 1999，p. 16)。なお，この大会は当初計画では前 年の 1990 年に開催予定であったが，「1991年 9 月 の第 11 回アジア大会北京開催のため」との理由 をもって延期された経緯がある。これは 1989 年 6 月に起きた天安門事件が大きく影響していると考 えられる。

1995 年 11 月には第 5 回大会が雲南省昆明市に て, 比賽は前回から実施の龍舟競渡, 搶花炮, 秋 千, 射驽, 珍珠球, 木球, 摔跤, 武術のほか, 新 たに建球，打陀螺を加えた 10 競技及び 129 の表 演が実施され，9,000名の関係者が集った（第 6 回全国少数民族伝統体育運動会拉薩分賽場専刊編 集部，1999，p. 16).4年後のマカオ返還を控え てマカオからも視察団を迎え, 中国人民解放軍と 新疆生産建設兵団が初参加した。
1999 年には第 6 回大会が国家民族事務委員会と 国家体育総局の共催により，ラサ市と北京市に分 けて，のべ 13 日間にわたって開催された. 大会 精神に「平等，団結，進歩，繁栄」を掲げ，目的 に「民族体育の発展，民族体質の増強，民族の団 結強化，民族精神の高揚」を高らかに謳い上げ， 国内外に「一つの中国」をアピールするものであ った。

ラサ大会は 8 月 18 日午前，ラサ市人民体育場 で開幕式及び， 7,000名のチベット族による祭典 が執りおこなわれ，中国国営通信・新華社は「ラ サの 1300 年の歴史で最も盛大な日」と報じた (朝日新聞電子版，1999.8.18）。そして23日まで の 5 日間，比賽は馬術，打陀螺，射驽，押加の 4 競技と表演が実施され約 1,200 名の選手が参加し た。このうち押加はチベット族，打陀螺はチベッ 卜族及びワ族，ヤオ族，チワン族などの西南少数 民族で主に実修されている民族スポーツであり， 本大会のチベット開催に合わせて比賽に正式採用 されたものであった。

北京大会は，ラサ大会から 1 力月後の 9 月 24 日 から 30 日まで開催された。 9 月 24 日夜, 北京工 人体育場にて開幕祭典が繰り広げられ，「錦紼中 華」が警察, 高校, 職域, 中央民族大学, 地方芸 術団などからの約 6,400 名によって盛大に演じら れた。そして，朱鎔基中国共産党中央政治局常務 委員・国務院総理（当時）が開会宣言を告げた。 この開幕式は「工人体育場にておこなわれたスポ ーツ・イベントのなかでも最大規模」（中華人民 共和国第六届少数民族伝統体育運動会組織委員 会，1999a）とされる。34代表団から 3,422名の 選手が参加し，国家オリンピック体育センターを 中心に比賽 10 競技及び 100 余りの表演が展開さ れた ${ }^{\text {ia }}$. 9 月 30 日午後, 警備によって封鎖され た天安門広場に隣接する北京人民大会堂での閉幕 式をもって全日程を終了した。

\section{III 第 6 回少数民族運動会にみる 文化的動態と政治的動態}

少数民族運動会及びそこで繰り広げられる民族 スポーツには，それをおこなう人々の文化が色濃 
く刻印されている.また, 少数民族運動会は国家 政策として開催されるものであり，そこには少数 民族政策が直接的に反映している.よって，本章 ではその変化を文化的動態と政治的動態という二 つの作業概念に分けて論じることによって, 少数 民族運動会をめぐる彼らのアイデンティティが浮 き彫りになってくると考える。

\section{1. 文化的動態}

はじめに大会名称の問題であるが，大会名を 「少数民族運動会」としながらも，実際には少な からず漢族が参加している．これは「民族形式」 として実施された 1953 年大会当初からのことで あり，「少数民族」を冠し「少数民族運動会」と 改称した 1982 年大会以降も引き続き漢族が参加 している．この状況を指して大会広報では，1995 年大会までは「55の少数民族」と少数民族のみ を取りまとめて表記していたものを，1999年大 会からは少数民族と漢族を一体化させた「56の 民族」へと変更した。

アジア的な民族モデルは, 何よりも共通の出生 の絆や土着文化を強調し, 民族は虚構の「超家族」, 成員はみな兄弟姉妹とする（スミス，1998，pp. 27-128).いわば土着主義的ナショナリズムとも いえるこの認識は, 大会歌「我愛中華」のなかに 明確に読み取ることができる. 少数民族と漢族を 一つにまとめ「56の星座，56の花，56族は兄弟 姉妹の一家」と謳い,「一つの中国」を強調しょ うとする意戝が达められていることを教える。ま た，そこでは民衆の動員が精神とレトリックにお いて重要な役割を果たす（スミス，1998，p. 36）. 少数民族運動会はまさに少数民族を動員する場で あり，そこでのレトリックには近代オリンピック との同型性，模倣性を指摘することができる.

マカルーン（1988, pp. 390-414）は近代オリ ンピックを, ゲーム, 儀礼, 祭典, スペクタルと いう4つのフレームによって多岐的に枠付けられ た文化的パフォーマンスと定義する. 少数民族運 動会にみる文化的パフォーマンスの顕著な事例の 一つが，今回から実施されたいわゆる「聖火リレ 一」である。この聖火採火のためにチベット族の
男女 10 名から成る登山隊が編成され，5月 27 日 に8,848メートルのチョモランマ峰で太陽光線か らの採火に成功し, ラサ大会開幕式へともたらさ れた（人民日報電子版，1999.2.8，5.21，5.28）。 そして，辺境の民族自治区であるチベットと首都 の北京を「民族の火」で結ぶべく空路にて運ばれ， 市内の天壇公園に設けられた「中華民族の世紀宝 鼎」に, 9 月 9 日 9 時 9 分 9 秒を期して少数民族と 漢族を代表した 9 名によって点火すべく計画され た（人民日報電子版，1999.8.25）。

ここでは, 聖火リレーのなかでも特にそのプロ セスが重視される。「中華民族聖火」は世界最高 峰で採火され, それを周縁から中心へ求心的に, そして現代から歴代皇帝の権威へと遡及的に結び つけた。聖火リレーはそれをおこなうもののアイ

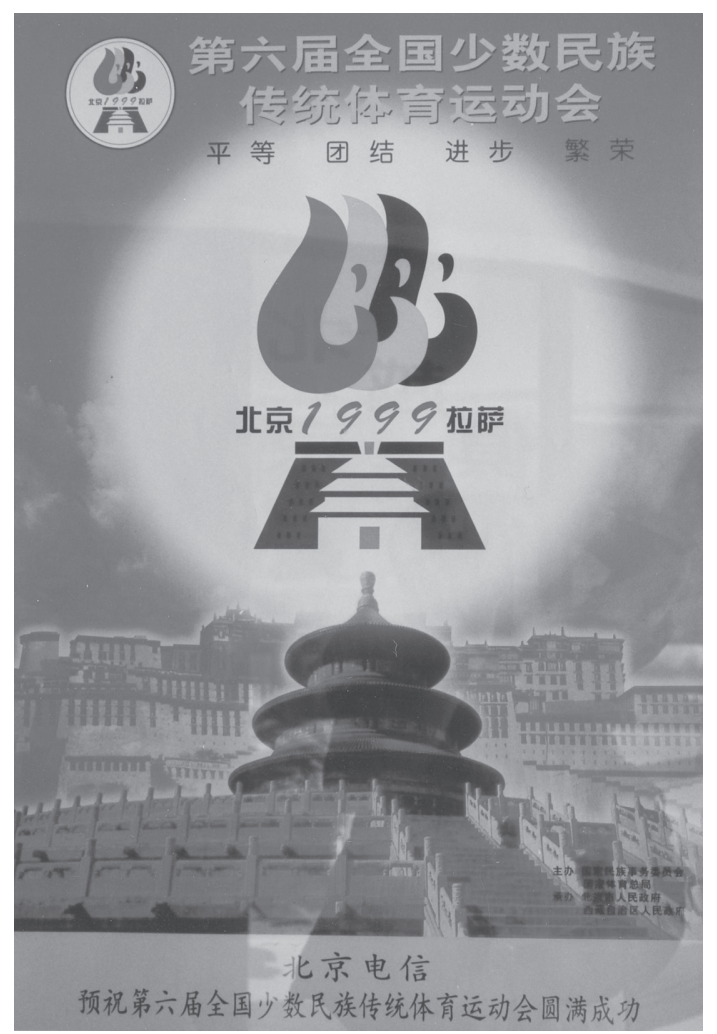

写真 1 第 6 回大会のポスター

上部のマークは天壇とポタラ宮で燃え盛る聖火を図案化 したもの. 3つの炎は「団結, 繁栄, 進歩」を, その形 は「6」をイメージする.下部は天壇とポタラ宮を組み 合わせたもの. 
デンティティを歴史的記憶の共有に求めるもので あり，可視的である故にイメージ構築を容易にす る.「9」という数字は「久」すなわち「永遠」に 通じ，また，その火種をかつて皇帝が天意をはか った天壇の円丘上に移すという象徵的行為によっ て, 中央政府の統治の正統性をスペクタクルに演 出した.

大会のスペクタル化の傾向は, 周到な演出が施 された開会式など随所に見ることができる。そし て，国家的一大祝祭として新聞，テレビなどの既 存のメディアはもとより, 今回より開設されたウ エブサイトに媒介され，競技場に参集した少数民 族と関係者にとどまらず，リアルタイムでグロー バルに共有することを可能にさせた.

さらに，実施される民族スポーツそのものもさ まざまな変化をみせた。 その一例として搶花炮 （qiang hua pao）を，具体的にはルール及び用具 の変化を取り上げる.

搶花炮は 2 つチームが 1 個の花炮をラグビー のように奪い合いゴールに持ち込めば得点となる ゲームである。もともとは，チワン族とトン族が 春節におこなう「花輪奪い」が起源であり, そこ にはさまざまな儀礼的行為が付随していた（中国 体育博物館, 1990, pp. 130-131). すなわち, も ともとの搶花炮は宗教的・祝祭的民族儀礼と相即 不離の関係性を結ぶ「スポーツ文化複合」（寒川, 1991，pp. 139-145）として, 実修する当該民族 の文化システムに基づく, 文化コードのなかで理 解され，そのことによってはじめて意味を有する ものであった.

今日，一般的におこなわれている搶花炮は儀礼 的側面よりも主催者（政府）の管理する娛楽的活 動としての側面が強くなっており, チワン族を越 えた広西省全体の行事として民族的帰属を意識さ せるような文化政策の一環となっている（塚田， 2001, pp. 90-106).

少数民族運動会では 1986 年大会から比賽に正 式採用されているが, 宗教的・祝祭的民族儀礼と は切り離され，勝敗を競うことに第一義的価值観 が置かれた「競技スポーツ」となっている. 1998 年の規則改正を受けて, 今大会から花炮とその発
射方法が改められた。

花炮はこれまで, 直径 5 センチメートルの鉄環 に赤い布を巻きつけたものを使用していたが，環 のなかに指を差し込んで持つために指を骨折する 事故が発生すること, また, 観客に配慮し, 視覚 的に分かりやすく, 花炮は約 3 倍の直径 14 セン チメートルの色鮮やかなゴム製へと変更された. 更に，ゲーム開始にあたって，火薬によって花炮 を飛ばしていたが群衆の中での火薬（爆竹）の使 用を禁じた法律に抵触すること, 競技者に危険が 伴うという理由により電動発射法が採用され, 火 薬の爆発に代わる効果音と硝煙も演出された. こ の爆発音と硝煙は搶花炮の民族的特色とされてお り, 大会公式ウェブサイトではこれらの変化を 「民族的特色からの現代化発展」と位置付けてい る.

他方，古代中国の文化遺産を民族スポーツとし て再生させ, 少数民族運動会に取り込むこともお こなわれている. その一つが今回から比賽に正式 採用された蹴球である。蹴球は石球を用いるゲー ムであり石球自体は古代遺跡からも数多く出土し ている. 北京市民族伝統体育協会によって, 清朝 の石球を蹴るゲームが再現され, 様々な場での 10 数年のデモンストレーションを経て本大会の 比賽として正式採用されるに至った。同様の事例 は表演のなかに数多く認めることができる.

\section{2. 政治的動態}

少数民族運動会はこれまで原則的に 1 つの都市 で開催されてきたが, 今回はラサ, 北京の $2 つ の ~$ 都市で実施された。その理由として, 公式には 「中国・建国 50 周年」と「チベット民主改革 40 周年」の二大慶事をあげている，だが，前者は政 治的要請に基づくものとしても，後者には一つの 大きな問題が影響していよう。それは，いわゆる 「チベット問題」である. 中央政府側の一元的価 值基準では「チベット解放」とするが, 対するチ ベット側の歴史観では, 「1956年のチベット民族 の独立運動が人民解放軍により鎮圧され，運動の 精神的支柱であるダライ・ラマ 14 世がインドに 亡命してから 40 周年」という見解も存在する. 
現在，中国では3つの分離・独立の動きがみら れる。それは台湾，新疆，チベットである（王， 2001，p. 104）。中国は憲法の前文で多民族国家 であることを明記し，エスニック・グループの国 家からの分離・独立の否定が大前提となってお り，少数民族，そして民族自治区で起こった「独 立」騒動は須く鎮圧してきた注13). その一方で, 行政区画として民族自治地方を設定し，民族自治 の権限を主体少数民族に与えるなど，諸民族の自 治権を認めている.

少数民族は，人口比のうえでは僅か 8 パーセン 卜強にしかすぎないが，民族自治地方の面積では 全国土の 3 分の 2 を占める。また，かつては結果 として少数民族の多くは辺境, 国境地帯に居住し ていたが，これらの地域への漢族の大量移入が進 行するなかで，少数民族人口のかなり多くが自ら の居住地から他の居住地区（漢族を主とする）へ と移り住む現象も起こっており，少数民族政策は これまでのようにひとすじなわでは立ち行かなく なってきている。

ラサでは 1987 年秋から度々デモがおこなわれ， 1989 年から 1 年 7 力月間，建国後初の戒厳令が布 告された。中央政府は，この「40周年」にあた りチベット統治の正統性とその実効性を宣伝する 政治キャンペーンに力を注いできており注14)，人 民日報には 1999 年の年頭からその傾向が顕著に うかがえた。

このように，少数民族運動会のチベット開催の 理由は, 大会を成功裏に導くことで中央政府のチ ベット統治及び少数民族政策の正当性を国内外に アピールできることと，またチベット問題に対す る国際社会の関心の高まりを背景に，チベット情 勢が再び不安定化することを警戒し，「祝賀」の 警備注 ${ }^{15)}$ として対応するためでもあったともみら れる。

また，この背景には経済・社会の大きな変動が あげられる。大会閉幕の 2 力月後の 11 月，中国 共産党中央経済工作会議において「西部大開発戦 略」の実施が決定され, 国家の地域政策の重点を チベット自治区，新疆ウイグル自治区を含む「西 部」(全国土の 71 パーセント) に置くこととした.
これは「改革・開放」政策により，中国東部沿岸 の先進工業地带と中・西部内陸の後進一次産品地 帯との間に，経済上の不平等が存在する「東西問 題」の克服と少数民族の遠心分離傾向を是正し国 家への求心力向上がねらいにあると考えられる.

\section{IV 民族スポーツによるアイデンティティ の形成}

\section{1.「少数民族の民族スポーツ」から「中国の 民族スポーツ」へ}

少数民族が主たる担い手となる全国的スポー ツ・イベントの歴史は扮抄むね 2 期に分けられ る。第 1 期は，国際スポーツが実施された 1953 年大会の段階。これは建国まもない時期に国威発 揚の一環として開催され，具体的には少数民族の なかから優れたアスリートを発掘する目的があっ たと考えられる，大会ではウエイト・リフティン グにて 10 名の中国新記録が樹立された（中国体 育博物館, 1990, p. 783).

文化大革命期をはさみ，第 2 期には，名称が少 数民族運動会と改称された 1982 年大会以降は民 族スポーツが実施されることとなった。1982年 大会はその過渡期として，中国における民族スポ ーツのなかでも特に漢族を中心に広くおこなわれ ているものを採用し，1986 年大会から少数民族 がおこなう民族スポーツが中心となり今日に至っ ている。

少数民族運動会にみる国際スポーツから民族ス ポーツ重視への転換は，少数民族のスポーツへの 国家的要請がトップ・アスリートの人材発掘か ら，民族スポーツのもつアイデンティティ形成機 能への期待に変化したためであると考えられる。 これは中国共産党の「伝統への復帰注 16) 」(横山, 2002，p. 124）と軌を一にするものであり，1980 年代以降の「改革・開放」により社会主義イデオ ロギーの求心力が色裉せ，それに変わるものとし て「愛国主義」がクローズ・アップされたことと 無関係ではない.

先述したように，1981年以降，民族スポーツ の全国的競技会開催を視野に入れて，民族スポー ツの地方別大会や競技別大会が開催されるなど， 
民族スポーツの全国組織化がなされていった。だ が，そこには大きな障壁があった。寒川（2004， p. 4）が「民族スポーツはこれをおこなう特定の 人間集団に担い手が限られるという意味で『閉じ た』といってよい」記すように，類似した形態の 民族スポーツであっても地域や集団ごとにルール や用具に差異が存在した。なぜならば，民族スポ ーツの多くは実修する当該以外の他者との競争を 前提とはしていないからである。

そこで，少数民族の民族スポーツは「洗練され， 競い合いに発展させ，さらに多くの人々に奨励さ れなければ」（邱，1995，p. 212）ならないとし て，1981年の少数民族スポーツ振興方針によっ て「特色あるものについては他民族もこれを実施 できるようルールを改め，整備して競技化した」 (李，1999, p. 51). 儀礼的行為に付随していた 民族スポーツから特に「競争」に関わる部分を抽 出し「競技」として特化させ，さらにルールや用 具の差異を中央政府が主導し統一化することで, 当該民族以外での実修を促すとともに競争を可能 ならしめた。

このことは，もともと実修していなかった他の 少数民族, そして漢族にも「異文化」である民族 スポーツをおこなわせることになったことを意味 する注 17 .

また，中央政府は 1985 年から 1990 年にかけて， 民族スポーツの保存・継承のため 676 種目採集し 整理をおこない，これに漢族の民族スポーツ 30 種目を加え, 中華民族伝統スポーツ文化体系を構 築した（李，1999，p. 51）。これは，「中国文化」 の再創造であり，この創られた中華民族伝統スポ ーツ文化体系に対し多民族国家の共通文化として の新たな真正性を付与させるための一つの場が少 数民族運動会であったといえる ${ }^{\text {i⿱ }}$ 18)。つまり，少 数民族運動会で実践される民族スポーツは，宗教 的・祝祭的民族儀礼としての意味合いや価值，あ るいは当該の民族（集団）から離れ，新たな少数 民族運動会という場でこれまでとは違った真正性 を獲得することとなった。

これにより，少数民族運動会の比賽に採用され た民族スポーツは，彼らの文化的枠組みの中にい
わば「閉じられたコード」として存在していた状 態から，他の少数民族，漢族に対しても開かれた 中国全体の「通文化的コード」へと変化した。す なわち，当該の少数民族だけが実修する特定の 「少数民族の文化」から，次いで 55 少数民族がお こなう「沉少数民族の文化」へ，そして「中華民 族の文化」へと漸次拡大した。これは, 主流社会 の漢族からみればマイノリティの「異文化」を 「自文化」に受容したといえるが，他方，民族ス ポーツが少数民族運動会の比賽種目として採用さ れることは，もともと実修してきた少数民族から みれば自文化が中央政府から国家的な認知を受け たことを意味する注 ${ }^{19)}$ 。いわば，民族スポーツの 国家による権威付けである.

グットマン（1997，pp. 2-13）は国際スポーツ を例にして，「合理化という側面からスポーツを ルールによって拘束し，組織の合理化を可能にさ せながら，新しいスポーツを誕生させ，今まで存 在してきた」とする。少数民族運動会における 「競技化の奨励」（邱，1995，p. 212）は国際スポ ーツをモデルとし，「少数民族の民族スポーツ」 を「中国の民族スポーツ」へ置換させるためにお こなわれてきたといえる。

少数民族運動会は「少数民族のスポーツの発展 を促進することを目的」（邱，1995，p. 210）と して開催されているが，そこには多民族国家の社 会的・文化的統一のためという政治的要請を明確 に読み取ることができよう。

\section{2. 民族スポーツから「ポスト民族スポーツ」} へ

少数民族運動会では少数民族が民族スポーツを 実践することによって, 少数民族としての自己像 を表象するとともに，アイデンティティの確認， 再生産，強化が図られる。だが，「競技化の奨励」 によって当該の文化システム, 文化コードから離 れたという点において, 彼らがもともと実修して いた民族スポーツとは文化的在りようが大きく異 なるといえよう。

寒川（2004, p. 7-8）はスポーツ文化複合の概 念について，一定の社会関係を有する人たちがお 
こなう民族スポーツは，それに関わる営みが社会 的に存在することを当該社会の精神文化が支え保 障していると説明する。これによれば，民族スポ ーツを当該社会の文化文脈のなかで読み解く場合 には，そこに立脚している社会文化，精神文化， 技術文化の諸要素に分類される「文化」がとりわ け重要視される。ところが，一方では民族スポー ツが「国際スポーツ化する際の精神文化の変容」 (寒川，2004，p. 12）といった問題も指摘する.

これまで，民族スポーツという分析概念は「こ れをおこなう民族の文化の枠を出ては生きられな いという性質を持っている」（野々宮, 1996, p. 227）と本質主義的な理解がなされてきたきらい がある注20).それにより，民族スポーツについて， 国際スポーツをモデルとして積極的にそのシステ ムを利用し「発展」が図られること，また当該の 文化領域を越境しておこなわれるようになったこ と, あるいはもともとの文化的脈絡から離れ再構 築されたことなどの文化変化についても，もっぱ ら民族スポーツの「近代化」，「近代スポーツ化」, または「国際スポーツ化」，「民族スポーツの国際 化」，として取り扱われてきた注21).

だが，このような民族スポーツをめぐる新たな 文化事象については，これまでの類概念としての 民族スポーツとは分けた方が当該スポーツと関わ る多様な文化的諸問題を明らかにするうえで，よ り有効に機能するであろう。そこで本稿では，民 族スポーツの文化変化の過程における連続性に鑑 み，「ポスト民族スポーツ」という新たな分析概 念を立てることとする注 22 .

少数民族運動会にみる民族スポーツから「ポス ト民族スポーツ」への変化は，「55の少数民族」 としての沉少数民族的アイデンティティに主流社 会の漢族を加え「56の民族」とすることで中華 民族的アイデンティティへ，さらには「人民」と しての国家的アイデンティティへの昇華をも容易 ならしめた.

これは，「55の少数民族」として漢族の対極に 位置付けるのではなく，漢族を含めることで「56 の民族」にステータスを上昇させ，そこから提供 される中華民族的アイデンティティを国家的アイ
デンティティに置換させることによって，国家と しての凝集力を生み出そうとしているといえよ う.そこにおいて，少数民族運動会は少数民族に $\lceil 55$ の少数民族」としての文化的共有性を持たせ， 漢族を核とすることで多民族国家の統合原理とし て置き換えさせる文化装置として機能している.

このことは，民族スポーツ，あるいは「ポス卜 民族スポーツ」が多民族国家の国民統合に寄与す る過程で，文化的，民族的，国家的，政治的にさ まざまに発現するアイデンティティの継承とその 変化の媒体となっていることを教える.

吉見（1992，pp. 262-263）は万国博覧会のも つ社会的機能に注目し，「その本質においてきわ めて政治的でもあれば，イデオロギー的でもある 文化の戦略的な場」とする。少数民族運動会は中 国文化を表象するという場であり，民族スポーツ の実践，あるいは視覚化によってもたらされる均 質な経験の共有がもたらされる。それにより，少 数民族に対して自身が中国文化の担い手であるこ とを認識させ，少数民族を「人民」に自己変化さ せる場であるといえる，まさに国家による文化の 戦略的な場である。

少数民族運動会において国家にとって重要なの は，少数民族として彼ら自身による民族的アイデ ンティティの獲得よりむしろ, 国家的アイデンテ イティをもつ均質な「人民」の育成といえよう.

\section{V おわりに}

これまで見てきたように，合理的な「科学的国 家」中国の少数民族スポーツ政策の一つである少 数民族運動会は, 外的には国際スポーツから民族 スポーツ重視への転換，内的には民族スポーツか ら「ポスト民族スポーツ」への変化がみられる。 また，少数民族運動会における文化の表象性も $\lceil$ 少数民族 $=$ 異文化」の状況から「少数民族 $=$ 自 文化」へと変化してきている。 そして, 少数民族 運動会は少数民族としての民族的アイデンティテ イと中華人民共和国の国家的アイデンティティと いう二つのアイデンティティを発露する場となっ ている.よって, 担い手の少数民族にとっては少 
数民族と「人民」との二つの自己を身に着けるこ となり，それぞれエスニシティとナショナリティ の発現となる。

こうした，さまざまなレベルのアイデンテイテ イの顕現によって，「民族平等，民族団結」の国 是のもとに民族融和政策を進める一方で「民族問 題」を抱える現代中国では，少数民族にとっては エスニシティとナショナリティの相克が, 中央政 府としては彼らにいかにその均衡を保たせ続ける かが多民族国家の将来にとって重要となってく る。まさに，少数民族政策は「両刃の剣」といえ よう.

2003 年 9 月に寧夏回族自治区銀川市で第 7 回大 会が挙行された。本研究では筆者が現地調査を実 施した 1999 年大会についての考察をおこなった が，第 7 回大会と比較検討することで，本論のテ ーマがより明らかにされると考える. 今後の課題 としたい.

\section{注}

注 1）1990年の全国人口センサスに基づく「中国民族 人口資料」による.

注 2）毛里によれば，現代中国では「国民」に代えて 「人民」を採用してきた特有の事情が存在し，周 恩来による人民と国民を社会主義の階級的立場 から峻別した説明（1949年 9 月，人民政治協商 会議）が，今もなお生き続けている（毛里， 2001， p. 30)。周恩来による説明，特に「人民」 の定義の特殊性は本稿の理解にとって重要であ るので，少々長いが一部引用する.

「人民」と「国民」の区別について少し説 明しなければならない。「人民」は労働者階 級，農民階級，プチブルジョア階級，民族 ブルジョア階級，それに反動階級だったが 目覚めた一部の愛国民主分子である。官僚 ブルジョア階級は……, 改造して新しい人 にしていくべきだが，改造前は人民の範疇 には入らない。 それでも中国の一国民であ り，当面彼らには人民の権利は与えられな いが，国民の義務は守らなければならない。 …‥つまり，国民には「人民の敵」も含ま れ，いわば中国の国籍をもつもの，公民に
ひとしい (毛里, 2001, p. 30).

よって，本稿は国家政策を取り扱うことから， 政治的アイデンティティに拠る限定的な概念で ある「人民」を用いる。また，本稿で扱われる 理論モデルや概念は少数民族運動会に限定され るものであることはことわっておく

注3）中華民国時代に唱えられていた「五族協和」は, 中国史上初めて複数の民族の協和という考えを 打ち出したものであったが，実際には漢族をそ の中心に置き，他の 4 族が漢族に同化することに よって達成される「調和」のことであり,「大漢 族主義」に他ならなかった。

注4）民族の認知にあたっては「歴史的に構成された, 人々の強固な共同体」というスターリンの民族 定義を揭げながらも，実践的には彼ら自身の 「民族意識」を特に重視し，それには民族学的調 查が重要な役割を果たした。

注5）1954年までに 29 族が，1965年までに 16 族が新 たに少数民族として認定され，1979年のジノー 族が加えられ 55 族となった。

注6）1979年に採用された「一人っ子政策」が少数民 族に比較的寛容であったこと，また，少数民族 に与えられている進学や就職の際の特別待遇を 得ようとしてのことであったとされる.

注7）インドネシアにおける村レベルの影絵芝居の事 例をもとに指摘する。

注 8）「比賽」は民族スポーツを共通ルールにて競う 「競技」のこと．「表演」は各々の少数民族固有 の，あるいは特色をもった民族スポーツによる 採点競技のこと.

注9）1982年大会は自動的に第 2 回とされた。

注 10）馬術のみ，同年 8 月にフフホト市で実施され た.

注 11）中華人民共和国は台湾に居住する少数民族を 「高山族」として一括しているが，中華民国（台 湾）は「原住民」として12族に区分している。 少数民族運動会に参加したのは，その民族衣装 などから推測して原住民諸族のなかでも最も人 口が多いアミ族と思われる。

注 12）他にも民族文化祭，民族芸術週間，民族交歓 会，民族写真展など少数民族をテーマとしたさ まざまな関連行事が催された。

注 13） 1980 年代後半には民族地区でエスノ・ナショ ナルな要求が噴出し, 政府が「民族分離主義」 
とみなして政治問題化した。1989年の天安門事 件，1991年のソ連邦崩壊に影響を受けて，民主 化運動や少数民族の独自性を求める動きに対し て当局は過敏なまでの対応を見せてきている.

注 14）大会期間中, チベット文化の象徴であるポ夕 ラ宮には「偉大なる中華人民共和国万歳」の垂 れ幕が掲げられた。

注 15）大会期間中，ラサ市内は人口と比較して多く の人民解放軍, 公安関係者の姿が目立ち, 競馬 場では約 1 メートル間隔で人民解放軍兵士が立ち 並ぶなど，人海戦術による厳戒態勢がしかれて いた。

注 16）横山は中国共産党の変化について,「全面欧化」 論から「半面欧化」論へ, そして「中国化」論 へと変遷しており，その流れを「伝統への復帰」 とする.

注 17）第 6 回大会には北京体育大学, 北京師範大学 の体育系学生が数多く動員された。

注 18）橋本（1999）によれば「文化の真正性」は常 に動態的に再構築されているものであり, 誰に とっての「真正性」であるのか, 誰によって主 張されるのか, あるいは求められるのかが重要 な問題であるとする.

注 19）この一例として, 朝鮮族を中心におこなわれ ているシルムを少数民族運動会の比賽にしよう とする動きがみられる。

注 20）寒川が「民族スポーツはこれを抢こなう文化 を離れては成立しないという閉じられたコード 体系として存在する.リンガフランカ（共通語） としての国際スポーツに比べ脆弱にみえるが, だからこそ民族アイデンティティの形成には抜 群の威力を発揮する」（寒川，1997， p. 6) と国 際スポーツとの対比のなかで特にその有効性を 論じた文脈から, 前段の部分のみが切り取られ, それにとらわれ過ぎてきた観が否めない. 研究 対象も民族的，伝統的，伝統的，伝承的，前近 代的, 地域限定的な形のものがもっぱら取り扱 われてきた。

注 21）この問題に関する研究としては, バスクの民 族スポーツについて論じた，竹谷和之（1990） エスニック・スポーッと近代化. 体育の科学, 40 (7)：528-532. があげられよう.

注 22）ここでいう「ポスト」とは，ポスト・モダン の概念が指し示すところとは同一ではない。時
間軸としての「後」を表す意味で「ポスト」を 用いる。 そもそも, マックス・ウェーバーによ る「近代」と「伝統」の二項対立的な概念が有 効であるかといった問題も存在する. そのこと もあり, 本稿では「伝統スポーッ」ではなく 「民族スポーツ」という言葉を用いている.

\section{文献}

朝日新聞電子版（1999）朝日新聞社：東京.

中国体育博物館・国家体委文史工作委員会編（1990）

中華民族傳統體育志. 広西民族出版社：中国.

中華人民共和国第六届少数民族伝統体育運動会組織

委員会（1999a）中華人民共和国第六届少数民族伝

統体育運動会ウェブサイト（http://minzuydh.bta. net.cn/)：中国.

中華人民共和国第六届少数民族伝統体育運動会組織

委員会（1999b）中華人民共和国第六届少数民族伝 統体育運動会総秩序冊：中国.

第 6 回全国少数民族伝統体育運動会拉薩分賽場専刊編

集部（1999）第6 回全国少数民族伝統体育運動会拉 薩分賽場専刊：中国.

第六届全国少数民族伝統体育運動会拉薩分賽場壽委 会宣伝部刊行物編輯部（1999）第六届全国少数民 族伝統体育運動会拉薩分賽場専刊：中国.

邱 玉才（1995）中国少数民族の伝統スポーツ. 伝 統スポーツ国際会議実行委員会編 21 世紀の伝統 スポーツ. 大修館書店 : 東京, pp. 206-216.

グットマン：谷川 稔訳（1997）スポーツと帝国： 近代スポーツと文化帝国主義. 昭和堂：京都.

橋本和也 (1999）観光人類学の戦略. 世界思想社 : 京都.

李 建国（1999）中国における少数民族スポーツ政

策. 体育科教育, 47 (10)：50-52.

マカルーン：光延明洋訳（1988）世界を映す鏡：シ ヤリヴァリ・カーニヴァル・オリンピック．平凡 社：東京.

宮永國子（2000）グローバル化とアイデンティティ. 世界思想社：京都.

毛里和子（1998）周縁からの中国：民族問題と国家. 東京大学出版会 : 東京.

毛里和子（2001）現代中国の構造変動 7 中華世界： アイデンティティの再編. 東京大学出版会: 東京. 野々宮徹（1994）スポーツの現在。稲垣正浩ほか 図説スポーツの歴史. 大修館書店：東京. 
岡本雅亨（1999）中国の少数民族教育と言語政策.

評論社：東京.

人民日報電子版（1999）人民日報社：中国.

スミス：高柳先男訳（1998）ナショナリズムの生命 力. 晶文社 : 東京.

寒川恒夫（1991） スポーツ文化複合. 体育の科学, 41 (2) : 139-145.

寒川恒夫（1997） スポーツ学への招待.アエラムッ クスポーツ学のみかた。朝日新聞社：東京.

寒川恒夫（2004）スポーツ人類学のパースペクティ

ブ. 寒川恒夫編 教養としてのスポーッ人類学. 大修館書店：東京.

塚田誠之（2001）チワン族の「三月三歌節」にみら
れる文化変容とその背景. 佐々木信彰編 現代中 国の民族と経済。世界思想社：京都.

王柯（2001）民族問題. 創土社編 中国年鑑 2001. 創土社：東京.

新華社（1999）中華人民共和国第六届少数民族伝統 体育運動会ウェブサイト（http://202.84.17.82/ myh/home.html)：中国.

横山宏章（2002）中華思想と現代中国. 集英社：東 京.

吉見俊哉（1992）博覧会の政治学. 中央公論社：東 京.

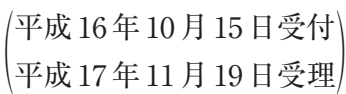

